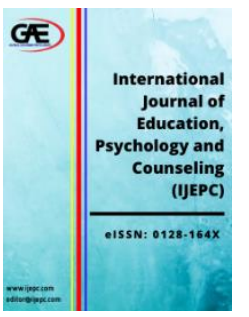

\author{
INTERNATIONAL JOURNAL OF \\ EDUCATION, PSYCHOLOGY \\ AND COUNSELLING \\ (IJEPC) \\ www.ijepc.com
}

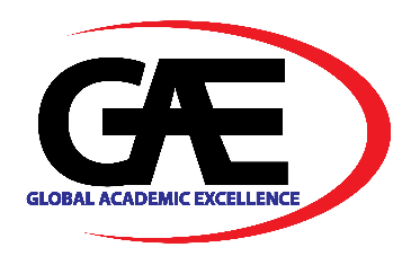

\title{
PROFESSIONAL DEVELOPMENT PROGRAMS AND EFL TEACHERS' TRAINING NEEDS: A SIMULATION STUDY
}

\author{
Mona Abdullah Alzahrani ${ }^{1 *}$, Faizah Mohamad Nor ${ }^{2}$ \\ 1 Department of TESL, Universiti Teknologi Malaysia, Malaysia \\ Email: m.abdullah-1985@graduate.utm.my \\ 2 Department of TESL, Universiti Teknologi Malaysia, Malaysia \\ Email: m-faizah@utm.my \\ * Corresponding Author
}

\section{Article Info:}

Article history:

Received date: 01.12 .2021

Revised date: 12.12 .2021

Accepted date: 28.12.2021

Published date: 31.12 .2021

\section{To cite this document:}

Alzahrani, M. A. \& Mohamad Nor, F. (2021). Professional Development Programs And EFL Teachers' Training Needs: A Simulation Study. International Journal of Education, Psychology and Counseling, 6 (44), 253-277.

\section{DOI: $10.35631 /$ IJEPC.644020}

This work is licensed under CC BY 4.0

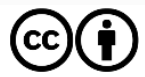

\begin{abstract}
:
Professional development programs (PDPs) are the door for teachers to learn and acquire the latest approaches in the teaching process. This study aimed to find out the EFL teachers' needs that should be incorporated in PDPs and the extent to which the current PDPs at Taif University English Language Center (TUELC) met the EFL teachers' needs. These aims were fulfilled through an explanatory sequential research design which used questionnaire and semistructured interviews. The findings revealed that teachers need to be trained on most of the proposed educational skills such as teaching skills, research skills, and management skills. Furthermore, the current study revealed that years of teaching experience is not a factor in determining EFL teachers' needs of PDPs. They also showed that the current PDPs have met EFL teachers' needs to some extent. However, there were few important needs that should be focused on during the designing of PDPs. Therefore, this study recommended to have needs analysis before conducting any training program as success of PDPs depends on identification and understanding teachers' perceptions and needs. Needs Analysis enables the training programs designers to focus on teachers' needs without wasting their time and efforts. This study contributed to the knowledge of EFL teachers' needs in PDPs which were identified based on its findings.
\end{abstract}

Keywords:

Professional Development; Teacher Education; EFL Teachers; EFL Teachers' Needs; PDPs. 


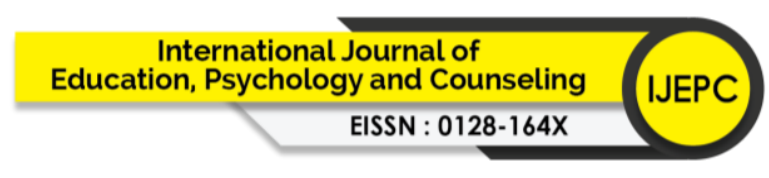

Volume 6 Issue 44 (December 2021) PP. 253-277

DOI 10.35631/IJEPC.644020

\section{Introduction and Background}

Teachers have an important role in education, and they must be well-prepared and continually since knowledge is always dynamic. They need to be engaged in professional development programs (PDPs) which make them up to date with the latest trends in the educational system. Also, teaching and learning patterns have changed towards a focus on learner independence and the role of the teacher is reduced to that of a facilitator and guide in the learning process. In this new rapidly changing educational reality, PDPs are one of the most important tools to help teachers in supporting their professionalism (Raud \& Orehhova, 2017).

Despite the fact that some teachers attempt to educate themselves via self-learning, having structured PDPs and training classes led by specialists for instructors in schools and universities is critical. If instructors are excluded from such programmes, they will not reach professionalism (Spencer, Harrop, Thomas, \& Cain, 2018). Thus, PDPs which include teacher training courses is one of the basic resources to implement professionalism and improvements in the education organizations. It leads to professional development (PD) in instructors' performance and, as a result, learning outcomes. (Boudersa, 2016; Oudah \& Altalhab, 2018; Raud \& Orehhova, 2017).

It is necessary for any educational institution either school or university to conduct such programs for their teachers especially language teachers due to this challenging era of language education. Non-native teachers who teach English language as a foreign language (EFL teachers) cannot be expected to be able to teach English courses without any special training (Wichadee, 2011). That is why English Language institutes from different countries have started to pay more attention to those programs. Lee (2016) claimed that professional development programs are essential to be a successful EFL teacher in Korea as well as in other parts of the world. Furthermore, Nijakowska, Tsagari, \& Spanoudis (2018) highlighted the demand for professional training programs of EFL teachers across the three countries of Greece, Cyprus, and Poland. In addition, Fang, Chan, \& Kalogeropoulos (2021) suggested that governments in Australia and Shanghai should consider further financial and time support for the professional development programs that were delivered to Australian and Shanghai EFL teachers. In Saudi context, most universities have either English Language Center (ELC) or English Language Institute (ELI). These centers or institutes have started to conduct PDPs to their staff in the last six years (Asmari, 2016; Hazaea, 2019; Roy, Rahim, \& Khojah, 2018; Tawalbeh, 2015). For the current study context, EFL teachers at Taif University-English Language Center (TUELC) in Saudi Arabia have involved in PDPs every semester since 2012.

However, conducting continuous PDPs is not the ultimate goal of the educational organization. The improvement of teachers' information and skills and consequently students' achievement is the goal of the PDPs. To have this required positive change that improves teachers' knowledge and practices and then students' learning, these programs should meet the teachers' training needs ( Zhang, Parker, Koehler, \& Eberhardt, 2015). Identifying the needs of teachers is believed to be a significant step in deciding whether or not training is required and defining what skills the training will provide the teachers with. According to the literature, building PDPs from the bottom up, based on teachers' training needs, is more useful than designing them from the top down (Darling-hammond et al., 2017 \& Macias, 2017). As a result, an efficient method of carrying out PDPs is to create a needs analysis instrument for teachers who will be involved in PDPs (Powell \& Bodur, 2019). 


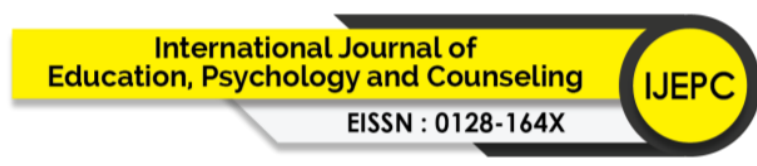

Volume 6 Issue 44 (December 2021) PP. 253-277

DOI 10.35631/IJEPC.644020

Identifying EFL teachers' needs help the designers of PDPs to incorporate these needs in PDPs created for their teachers to achieve the required improvement on teachers' and students. Adults can learn what they need to know based on the principles of Malcom Knowles' adult learning theory (Knowles, Holton \& Swanson, 2014). Thus, learning will not happen till there is a need for it. Powell \& Bodur (2019) ensured that the PDP should meet teachers' needs as adult learners with learning goals encourage the quality teaching and learning.

Although the impact of PDPs begins with understanding of teachers' training needs and their varied backgrounds (Darling-hammond et al., 2017; Qian et al., 2018), unfortunately, needs consideration is commonly overlooked as a first crucial step in most teacher training programs. This kind of ignorance results in a waste of time, resources and money, thus destroying the motivation and excitement of most teachers involved in these programs (Moeini, 2008). Therefore, to have effective programs that impact teachers' outcomes positively, the needs and dispositions of teachers should be considered in planning and implementing these programs (Topkaya \& Çelik, 2016).

It was mentioned by some researchers e.g. (Moeini, 2008; Qian et al., 2018; Topkaya \& Çelik, 2016), that the teachers' needs analysis is a very important step before conducting any training program in order to get the required results from these programs. Tawalbeh (2015) conducted a study at Taif University English Language Center (TUELC) to explore the EFL instructors' perceived effectiveness of professional development programs. The findings revealed that the real needs of teachers were not addressed when designing these programs, that is why it has been strongly recommended that a needs assessment should be carried out before planning PDPs. It is also suggested by Asmari (2016) that the continuous professional development designers and teacher educators should conduct a careful need analysis before planning and implementing PDPs for English language teachers.

Although PDPs play a crucial role in changing higher education teachers' practices and attitudes towards PDPs and subsequently students' outcomes, few studies have focused on this topic particularly in Saudi Arabia. Furthermore, there are no recordings or research -to the knowledge of the researcher- that show the extent to which the current PDPs met EFL teachers' needs. Hence, this mixed method study attempted to contribute to the knowledge base by investigating the EFL teachers' needs and the extent to which the PDP at TUELC meets EFL teachers' training needs. Therefore, the research questions that this study tried to answer were: what are the training needs of EFL teachers that should be addressed in PDPs? and to what extent are the training needs of EFL teachers met in the PDPs undertaken at TUELC?

\section{Methodology}

\section{Research Design}

To answer the research questions of the study, the researcher used a mixed method approach which entails collecting, analysing, and synthesising quantitative and qualitative data at some stage throughout the study process (Creswell \& Clark, 2018). The current study's explanatory sequential design comprised first obtaining quantitative data and then explaining the quantitative findings with in-depth qualitative data. As a result, there were two stages. To begin the quantitative portion of the project, a questionnaire was gathered from TUELC EFL teachers to identify the needs of the EFL teachers. Secondly, the qualitative phase using semi-structured interview was conducted as a next step to the quantitative results to help explaining the 


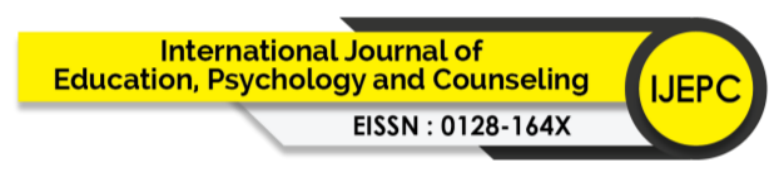

Volume 6 Issue 44 (December 2021) PP. 253-277

DOI 10.35631/IJEPC.644020

quantitative results and to examine the extent to which the identified EFL teachers' needs were met in the undertaken PDP.

\section{Population and Sampling}

EFL teachers at TUELC represented the population of the current study. They were 87 teachers from various nations and with a variety of degrees. In terms of quantitative sampling, the researcher surveyed all 87 EFL teachers. Total population sampling is the term used to describe this sampling technique. It is a form of purposive sampling strategy that entails surveying the whole population who share familiar traits with the topic being examined (Laerd.com, 2020). The shared features of EFL instructors at TUELC are that they all teach English as a foreign language to first-year students at Taif University (TU) and are all engaged in the PDP that is being investigated in this study.

The researcher employed purposeful sampling in the qualitative phase of the study, which is a form of non-probability sampling strategy that allows researchers to pick participants on purpose (Creswell \& Clark, 2018). It was proposed by Creswell and Clark (2018) that the follow-up qualitative phase participants be a minor group of participants who participated in the quantitative data collection since the explanatory sequential design tries to explain early quantitative results. As a result, a more efficient method of guiding the future sampling operations is to use the quantitative statistical results to pick the people who are best equipped to describe the interested phenomena (Creswell \& Clark, 2018). According to Palinkas et al., this type of purposeful sampling is known as criterion sampling (2015). After reviewing the quantitative data, the criteria for choosing participants were defined. These requirements were as follows: they should have participated in PDPs for at least two years, had more than five years of teaching experience, and their majors were in English language, TESL/TESOL, or Linguistics Studies. The qualitative sample should be substantially lower in size than the first quantitative sample (Creswell \& Clark, 2018). Therefore, the sample size for the interview data collection was eight instructors since the researcher achieved saturation at teacher number eight.

\section{Instruments}

The current study's data was gathered using two types of research tools which were a questionnaire and a semi-structured interview. The questionnaire, which is divided into two components, was sent to EFL teachers at TUELC. The first section contains demographic information on the respondents, such as nationality, qualification, teachers' major, and years of teaching experience.

The second section of the questionnaire aims to identify the EFL teachers' training needs that should be addressed in PDPs. This section was adapted from Shabani, Alibakhshi, Bahremand, \& Karimi (2019). Permission for adapting it was granted to the researcher through email communication with Goudarz Alibakhshi, an assistant professor at Allameh Tabataba'i University. The items of this section were slightly modified to be more comprehensive. Research skills category was added as the respondents of this study are university teachers. It is a Likert-type scale with five responses (not at all needed=1, slightly needed=2, somewhat needed $=3$, fairly needed $=4$, highly needed $=5$ ). The items are divided into eight main categories: content knowledge (6 items), teaching skills ( 7 items), management skills (6 items), educational technology (4 items), educational psychology (4 items), material development (4 items), assessment literacy (6 items), and research skills (4 items). 


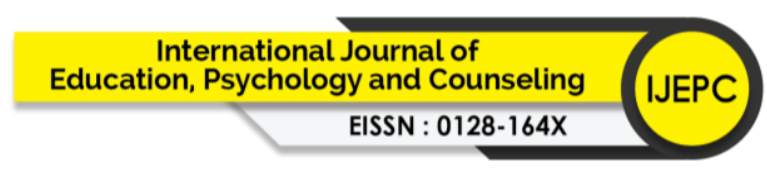

Volume 6 Issue 44 (December 2021) PP. 253-277

DOI 10.35631/IJEPC.644020

The qualitative phase in explanatory sequential design is referred to as follow-up data collection, and during this phase, the researchers determine which of the quantitative findings require additional explanation through qualitative data collection. Researchers must first examine the quantitative data to determine which are ambiguous or unexpected and require more explanation (Creswell and Clark, 2018) Thus, a semi-structured interview was employed after analysing the questionnaire results to obtain data from instructors in the qualitative phase of this study.

An interview guide with a list of themes to be investigated was created by the researcher with some additional open-ended questions to be asked in the semi-structured interviews. These questions should elicit candid replies from participants (Brown \& Danaher, 2019). This interview guide was divided into two parts. The first one focused on the training needs of EFL instructors, and the second one the extent to which these needs were addressed.

Because of the COVID-19 epidemic, online interviews through Zoom sessions were used. The timings of the interviews were chosen based on the convenience of the participants. In addition, the interview guide began with a topic description, and general questions that were asked about teachers' background (Liem, 2018). With the participants' agreement, all interviews were audio-recorded, and the interview sessions lasted 30 to 45 minutes. Participants were invited to elaborate on their responses in order to obtain additional information and clarify their ideas and thoughts.

\section{Data Analysis}

In the explanatory sequential design, data analysis occurs in three phases: quantitative data analysis, qualitative data analysis, and how the qualitative results helps to explain the quantitative ones (Creswell \& Clark, 2018). Statistical Package for Social Sciences (SPSS) was initially utilised in the analysis of quantitative data to generate descriptive statistics on the training needs of EFL teachers. For each statement in the questionnaire, the mean and standard deviation were computed. Then, an independent-samples T-test was used to see if there are statistically significant variations in ranking the needs of PDPs that correlate to differences in instructors' experience.

Thematic analysis, on the other hand, was employed for qualitative data analysis since it delivers rich, comprehensive, and complicated data. Thematic analysis is seen to be the best fit for any study that employs interpretations. It enables the researcher to link the frequency of the topic with the entire content (Alhojailan, 2012). Qualitative research thematic analysis may be broken down into five stages which are compiling, disassembling, reassembling, interpreting, and concluding (Castleberry \& Nolen, 2018). The first phase, compiling, was completed by transcribing the interviews on the otter.ai website. The use of the otter.ai website facilitated the transcribing process. Aside from that, the data is kept private and may be removed at any time. The next four steps were carried out using the Maxqda 2020 programme, which was used to arrange the data in order to discover common concepts, themes, and codes.

\section{Results and Discussion}

\section{The Training Needs of EFL Teachers That Should Be Addressed in PDPs}

Research question one seeks to investigate the EFL teachers' training needs that should be discussed in PDPs. The data collected via teachers' questionnaire and interviews. They were 


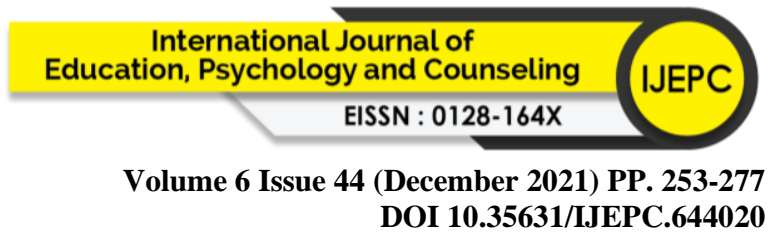

given a questionnaire in which 41 items (Section 2) identify EFL teachers' training needs that include eight dimensions, namely content knowledge, teaching skills, management skills, educational technology, educational psychology, material development, assessment literacy, and research skills. Then, eight selected teachers were interviewed to help explaining the quantitative results of research question one. The participants were instructed to rate each of the eight dimensions based on their perceptions of how necessary they consider professional development on that topic to be. Five-point Likert scale was used for rating the questionnaire items to answer this question. Since the Likert scale is considered an interval scale, the data was interpreted by three levels based on the range as shown in Table1. The greater the mean value, the greater the level of need.

Table 1: Mean Range Levels

\begin{tabular}{|c|c|c|c|c|c|c|}
\hline Scale & & $\begin{array}{l}\text { Interval } \\
\text { Length }\end{array}$ & $\begin{array}{c}\text { Lower } \\
\text { Limit }\end{array}$ & $\begin{array}{l}\text { Upper } \\
\text { Limit }\end{array}$ & Range & Level \\
\hline Not at All Needed & 1 & 1.33 & 1.00 & 2.33 & $1.00-2.33$ & Low \\
\hline Slightly Needed & 2 & & & & & \\
\hline Somewhat Needed & 3 & 1.33 & 2.34 & 3.67 & $2.34-3.67$ & Moderate \\
\hline Fairly Needed & 4 & 133 & 368 & 500 & $368-500$ & Hioh \\
\hline Highly Needed & 5 & & & & & \\
\hline
\end{tabular}

Once all data were collected, responses were run through descriptive statistical analysis on SPSS. Means and standard deviations were generated for each item in measuring the needed dimensions to be trained on. Table 2 shows the tabulation of means according to each item in the questionnaire.

Table 2: Mean and Standard Deviation for Items of Teachers' Training Needs

\begin{tabular}{|c|c|c|c|c|}
\hline Dimension & $\mathbf{N}$ & Item & Mean & Std. \\
\hline \multirow{6}{*}{ 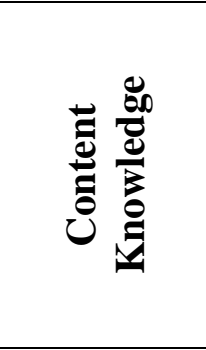 } & 1 & $\begin{array}{c}\text { Grammar, syntax, semantics, and } \\
\text { pragmatics }\end{array}$ & 3.22 & 1.359 \\
\hline & 2 & Phonetics, morphology, and phonology & 3.07 & 1.362 \\
\hline & 3 & Discourse analysis and stylistics & 2.93 & 1.218 \\
\hline & 4 & Psycholinguistics and sociolinguistics & 3.18 & 1.262 \\
\hline & 5 & Language Acquisition & 3.61 & 1.341 \\
\hline & 6 & Applied linguistics and cognitive linguistics & 3.38 & 1.383 \\
\hline \multirow{7}{*}{ 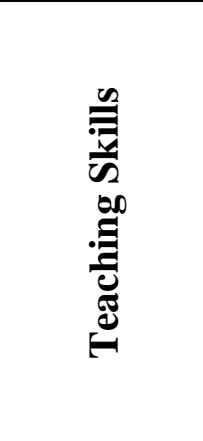 } & 7 & Teaching Productive Skills & 3.82 & 1.451 \\
\hline & 8 & Teaching Receptive Skills & 3.75 & 1.488 \\
\hline & 9 & Teaching Vocabulary & 3.61 & 1.543 \\
\hline & 10 & Teaching Language Functions & 3.63 & 1.487 \\
\hline & 11 & Teaching Mixed-Ability Students & 4.08 & 1.203 \\
\hline & 12 & Learner-centered Approaches & 4.03 & 1.393 \\
\hline & 13 & $\begin{array}{l}\text { Teaching Methodology e.g. Team } \\
\text { Teaching, Task-based Teaching, } \\
\text { Communicative Teaching ...etc. }\end{array}$ & 4.05 & 1.320 \\
\hline \multirow{4}{*}{ 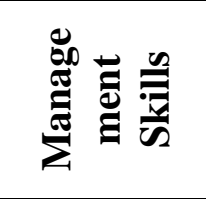 } & 14 & Creating Relaxed Atmosphere & 3.60 & 1.490 \\
\hline & 15 & Discipline Strategies and Skills & 3.62 & 1.358 \\
\hline & 16 & Time Management & 3.41 & 1.589 \\
\hline & 17 & Activities Management & 3.53 & 1.546 \\
\hline
\end{tabular}


International Journal of

Volume 6 Issue 44 (December 2021) PP. 253-277

DOI 10.35631/IJEPC.644020

\begin{tabular}{|c|c|c|c|c|}
\hline & 18 & Group work / Pair work Management & 3.67 & 1.499 \\
\hline & 19 & Large Classes Management & 4.14 & 1.340 \\
\hline \multirow{4}{*}{ 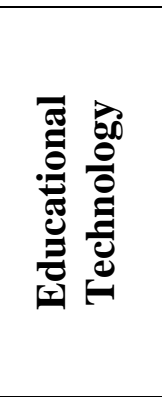 } & 20 & $\begin{array}{l}\text { Using Technology-Assisted Language } \\
\text { Learning (TALL) e.g. E-Learning, Mobile } \\
\text { Learning, ...etc. }\end{array}$ & 3.78 & 1.333 \\
\hline & 21 & $\begin{array}{l}\text { Using New Media for Teaching and } \\
\text { Learning }\end{array}$ & 3.85 & 1.377 \\
\hline & 22 & Creating and Using Blogs and Wikis & 3.62 & 1.213 \\
\hline & 23 & $\begin{array}{l}\text { Using platforms such as: Blackboard, } \\
\text { CLMS, Edmodo, ...etc. }\end{array}$ & 3.61 & 1.528 \\
\hline \multirow{4}{*}{ 苞 } & 24 & Enhancing Students' Motivation & 3.91 & 1.361 \\
\hline & 25 & Enhancing Students' Autonomy & 4.05 & 1.210 \\
\hline & 26 & Enhancing Students' Confidence & 3.98 & 1.329 \\
\hline & 27 & Enhancing Teachers' Self Esteem & 3.76 & 1.430 \\
\hline \multirow{4}{*}{ 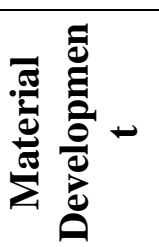 } & 28 & Developing Lesson Plan & 3.10 & 1.502 \\
\hline & 29 & Textbook Evaluation & 3.46 & 1.310 \\
\hline & 30 & Material Development/Adaptation & 3.57 & 1.352 \\
\hline & 31 & Designing Syllabus & 3.47 & 1.371 \\
\hline \multirow{6}{*}{ 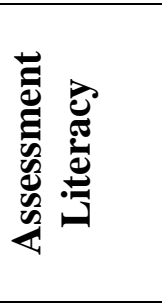 } & 32 & Innovation in Assessment & 3.72 & 1.117 \\
\hline & 33 & Test Development & 3.82 & 1.234 \\
\hline & 34 & Test Psychometrics & 3.46 & 1.199 \\
\hline & 35 & Formative and Summative Assessment & 3.72 & 1.300 \\
\hline & 36 & Online Assessment & 3.85 & 1.317 \\
\hline & 37 & Correction Codes & 3.60 & 1.325 \\
\hline \multirow{4}{*}{ 爮 } & 38 & Academic Writing & 4.16 & 1.238 \\
\hline & 39 & Publishing Scientific Articles & 4.09 & 1.187 \\
\hline & 40 & Research Methods and Techniques & 4.13 & 1.159 \\
\hline & 41 & $\begin{array}{c}\text { Data Analysis Programs e.g. SPSS, } \\
\text { STATA, R, .. etc }\end{array}$ & 4.00 & 1.131 \\
\hline
\end{tabular}

Table 2 shows that the mean scores of all items in the questionnaire fall within the range of 2.93 to 4.16. This means that the level of need for all mentioned items is either moderate or high. The item that received the highest mean score is Item 38 with a mean score of 4.16 and standard deviation of 1.238 . This item is about academic writing which signified the most needed topic to be trained on. The respondents of this research question were university teachers, and it is known that instructors at universities need to write academic articles to publish them. That is why the item of academic writing has got the highest mean score. This finding is in line with NaliakaMukhale \& Hong (2017) where they mentioned that one of the professional development needs of lecturers at universities was academic writing skills to write good research articles and publish them in indexed journals. Furthermore, Subekti (2020) recommended English teachers to undergo further training on various aspects of writing a research report. He suggested conducting a specific training on how to use the correct keywords to search for relevant academic sources in order to write a good literature review in a research article. Also, he recommended to have training on the use of reference and citation manager 


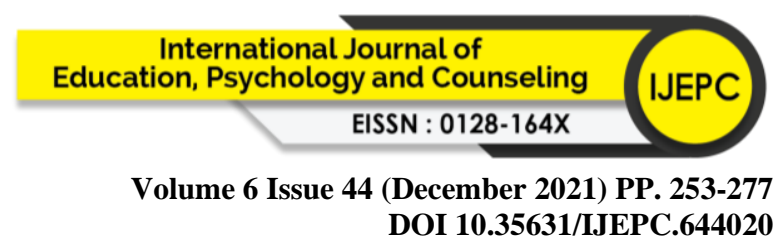

such as Mendeley. All of these suggestions will help in improving the academic writing of research articles.

On the other hand, the item that has the lowest mean is Item 3 with a mean score of 2.93 and standard deviation of 1.218. This item is about discourse analysis and stylistics. It means that teachers rated this item as the lowest need to be trained on. Some teachers' responses during the interview also revealed the same finding. They stated that they did not need complete training sessions in this very detailed content knowledge aspects. Two of them expressed that:

"I don't think it's necessary, we may all have the similar information about the content. But there is always something to add, and it could be in a way of sharing experiences or ideas about specific topic, but not to learn something completely at training sessions." (Teachers' Training Needs $>$ Content knowledge> T2).

"In fact, they are important, but they shouldn't be a central. It means a teacher must have a good background about them, but for the learner, I think they are not as important as other skills, because students or some learners are not specialists in English language. So, the concentration will be on the other factors not in these issues like, discourse analysis and stylistics, phonology, morphology and so on." (Teachers' Training Needs > Content knowledge> T5.

The excerpts above show that teachers should have good background about the content knowledge of English language but not with very detailed issues because the students are not specialists in English as T5 expresses. They just take the course as a general subject, and they do not need to know about specific topics like discourse analysis or stylistics. Also, T5 mentions that all EFL teachers have the basic knowledge and there is no need for complete training sessions about these aspects of the language. They can only share their ideas and experiences together in informal sessions.

Upon generating the means for individual items, the items were then computed according to the eight domains of the training needs. Table 3 below shows the tabulation of the mean and standard deviation according to these domains.

Table 3: Mean and Standard Deviation of Training Needs' Dimensions

\begin{tabular}{cccc}
\hline Dimensions & Mean & Std. & Rank \\
\hline Content Knowledge & 3.23 & 1.017 & 8 \\
Teaching Skills & 3.85 & 1.255 & 3 \\
Management Skills & 3.66 & 1.328 & 6 \\
Educational Technology & 3.82 & 1.125 & 4 \\
Educational Psychology & 3.92 & 1.221 & 2 \\
Material Development & 3.40 & 1.171 & 7 \\
Assessment Literacy & 3.70 & 1.088 & 5 \\
Research Skills & 4.10 & 1.006 & 1 \\
\hline
\end{tabular}

From the table above, it could be seen that all the eight dimensions got a mean score which fall within the range of 3.23 to 4.10 . This reading shows that the level of need for all the mentioned dimensions is either moderate or high. A comparison of the means shows that teachers gave Copyright $\odot$ GLOBAL ACADEMIC EXCELLENCE (M) SDN BHD - All rights reserved 


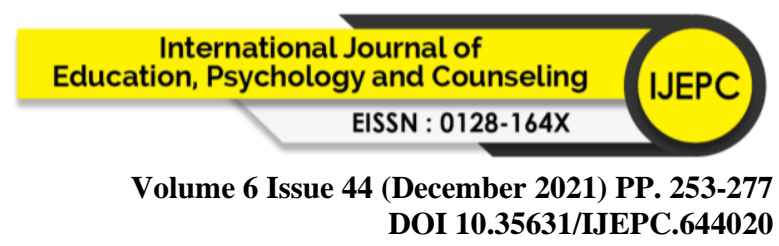

Research Skills the highest overall rating with a mean score of 4.10 and standard deviation of 1.006. This indicates that EFL teachers at university need more training on research skills. This result is in line with Czerniawski et al. (2018) where research skills emerged in the next often mentioned list of the training needs for EFL instructors. Likewise, Hazaea (2019) discovered that EFL instructors required additional research training workshops on topics such as research methods and journal publication. Teachers' responses during the semi-structured interview showed the reasons behind this results as follows:

"Yes, there are some professors at ELC, I think for them it would be important to have training sessions in research skills." (Research Skills> Important for professors $>$ T1).

"Yes, of course, they are important of course, because as university teachers, and at this level, of course, we need also to develop and increase our research skills to be the best." Research Skills> University Teachers $>$ T4).

"Research skills are important especially that many teachers now are taking their MA or PhD So they need to be aware of the research skills." (Research Skills > Completing their Study> T8).

Based on the excerpts above, all T1, T4, and T8 agreed that the training sessions in research skills are important to be included in PDPs. One of the reasons mentioned by T1 is that there are professors at English Language Center (ELC), who completed their $\mathrm{PhD}$, and they need to publish articles. So, it is beneficial for them to have training in academic writing and journal publications. Furthermore, as university teachers, they need to improve their research skills according to what T4 has said. Academics need to conduct research to either solve problems happening in the classrooms or to participate in the scientific research deanship that encourages university teachers to do research. Finally, T8 stated that many teachers now are completing their study and taking their MA or $\mathrm{PhD}$. So, they need to be aware of research skills in order to help them get their qualification.

On the other hand, although Content Knowledge has the lowest rating with a mean score of 3.23 and standard deviation of 1.017. This means that content knowledge is the area that is perceived to be the least important to be incorporated in training programs. A teacher in the interview stated that, while content knowledge is an essential issue to be instructed on, but there was no need for comprehensive training sessions in it. They stated that discussing ideas with peers could help teachers improve their content knowledge. The following is an excerpt that expressed this idea.

"I don't think it's necessary. Although there is always something to add and something to learn, but it could be on the way of sharing experience or ideas about specific topic in the content knowledge. Not to learn something completely via training sessions." (Content knowledge>Low Need for Training > T2). 


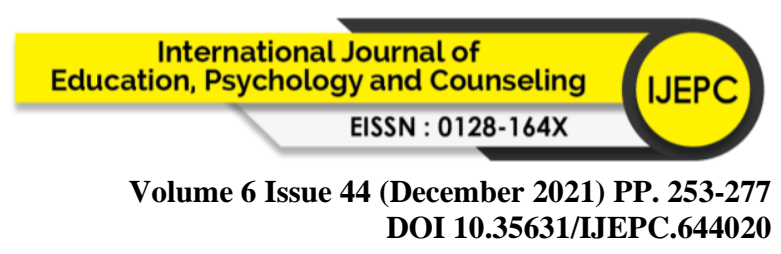

Another reason is mentioned below by T5:

"In fact, it is important, but it shouldn't be a central. It means a teacher must have a good background about content knowledge. Yeah, any teachers need to have information about all these things, grammar, syntax, semantics, but I think they are not as important as other teaching skills, because some learners are not specialists in English language. They use English as a medium of communication with others. So, the concentration will be on the other factors not in these issues just like, phonology, morphology and, and so on." (Content knowledge > Low Need for Training > T5).

T5 stated that it was important to have good content knowledge, but it was not necessary to be trained on like other dimensions such as teaching skills. She added because the students they taught were not specialized in English and they just used English as a way of communication, there is no necessity to focus on syntax, morphology, or phonology.

Although content knowledge has the lowest mean score (3.23) among the other training needs, it is still in the moderate level of need. This means that EFL teachers still need to be trained on this domain. NaliakaMukhale \& Hong (2017) found that content knowledge was one of the most important training needs for EFL teachers at universities. They stated that in order to achieve the intended learning outcomes, teachers must be proficient in their areas of specialization. Besides that, the study of Shabani, Alibakhshi, Bahremand, \& Karimi (2019) revealed that if EFL teachers want to maintain updated, they need to be involved in in-service courses on linguistics knowledge and metalinguistic. The same finding was also reported by Zein (2016) and Raud \& Orehhova (2017). They mentioned that one of the EFL teachers' professional development needs was improving their language proficiency which is part of content knowledge. This result could also be seen in the expressions of the teachers themselves during the interview as follows.

"Ifeel it's important, because it's a language and without these core knowledges of language, the teacher might lack some perspectives when she teaches the language. So, from my point of view, I feel it's crucial for each teacher to know at least, the basic knowledge of each of these content knowledge aspects." (Content knowledge > Important Training Need > T3).

\footnotetext{
"I do believe Yes. I've encountered some of the problems with teachers when I was a mentor. Some of them do have some problems in pronouncing some words or in understanding a grammar rule. So, she delivers it in a very, let's say complicated or sometimes having mistakes

in delivering some of the lessons. So yes, content knowledge is important." (Content knowledge >Important Training Need> T6).
}

From the excerpts shared above, it could be noticed that T3 and T6 agreed on the importance of having training sessions in content knowledge. They confirmed that teachers needed to improve the core skills of language such as pronunciation and grammar which influence their proficiency and as a result have effects on their teaching practices. Therefore, what teachers are trying to convey inside the classroom, will be acquired by their students. So, if teachers 


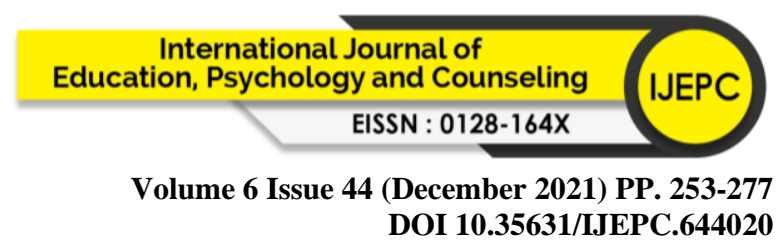

have problems with the content knowledge of the language, this will affect the students' outcomes severely. NaliakaMukhale \& Hong (2017) stated that developing teachers' knowledge and pedagogy would consequently enhance students' learning outcomes. So, in order to achieve the desired learning results, teachers must be knowledgeable in their areas of specialization.

\section{Comparison of Training Needs According to Teachers' Experience}

Teachers were placed into two groups based on their level of experience. The first group included teachers with five years and less teaching experience, and the other group contained teachers with more than five years of teaching experience. To determine if there are statistically significant differences in assessing the needs of PDPs that correspond to variations in teacher experience, Independent-samples T-test was conducted. First, means and standard deviation of each domain for both groups were tabulated. Table 4 shows the results of the tabulation.

Table 4: Comparison of Means and Standard Deviations of Teachers According to their Experience

\begin{tabular}{llcccc}
\hline Training Needs & \multicolumn{1}{c}{ Experience } & N & Mean & $\begin{array}{c}\text { Mean } \\
\text { Difference }\end{array}$ & $\begin{array}{c}\text { Std. } \\
\text { Deviation }\end{array}$ \\
\hline Content Knowledge & 5 years and less & 42 & 3.2143 & 0.0338 & 1.09153 \\
& More than 5 years & 45 & 3.2481 & & .95520 \\
Teaching Skills & 5 years and less & 42 & 3.8673 & 0.0292 & 1.30451 \\
& More than 5 years & 45 & 3.8381 & & 1.22194 \\
Management Skills & 5 years and less & 42 & 3.5437 & 0.2267 & 1.47153 \\
& More than 5 years & 45 & 3.7704 & & 1.18508 \\
Educational Technology & 5 years and less & 42 & 3.4762 & \multirow{2}{*}{0.4627} & 1.28168 \\
& More than 5 years & 45 & 3.9389 & & .98879 \\
Educational Psychology & 5 years and less & 42 & 3.7857 & \multirow{2}{*}{0.2643} & 1.42983 \\
& More than 5 years & 45 & 4.0500 & & .98656 \\
Material Development & 5 years and less & 42 & 3.2619 & 0.2714 & 1.23213 \\
& More than 5 years & 45 & 3.5333 & & 1.10859 \\
Assessment Literacy & 5 years and less & 42 & 3.6190 & \multirow{2}{*}{0.1476} & 1.22822 \\
& More than 5 years & 45 & 3.7667 & & .94775 \\
Research Skills & 5 years and less & 42 & 4.0238 & \multirow{2}{*}{0.1373} & 1.03419 \\
& More than 5 years & 45 & 4.1611 & & .98592 \\
\hline
\end{tabular}

Table 4 shows the means and standard deviation of each domain for both groups. The results reveal that for all the dimensions of the training needs the mean scores of teachers with more than five years of experience are higher than the teachers with experience of five years and less except for Teaching Skills. This means that those with more teaching experience need to be trained on the seven domains more than those with less teaching experience. This finding indicates that the experienced teachers expressed their need for more training as they felt that they had not undergone enough training due to their workload as they have administrative duties besides their teaching tasks. Therefore, they did not have enough time to attend the previous PDPs.

Going into more details, it could be seen from Table 4 that the mean scores of both groups in Content Knowledge are the least, with 3.2143 and 3.2481, respectively where the mean score 


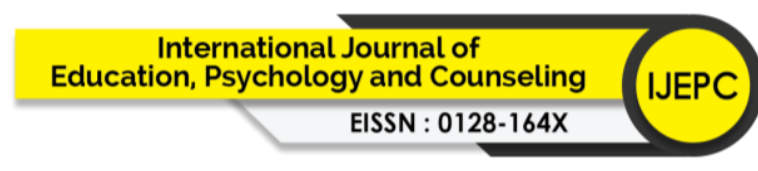

Volume 6 Issue 44 (December 2021) PP. 253-277

DOI 10.35631/IJEPC.644020

of experienced teachers is slightly higher by 0.0338 . This result demonstrates that both groups of teachers need a few training sessions on content knowledge as has been discussed before.

The finding of Content Knowledge is reversed for Teaching Skills domain where teachers with less experience have a mean score of 3.8673 and those with more experience have a mean score of 3.8381, with a mean difference of 0.0292 which represents the least mean difference between both groups. Although both experienced and novice teachers have almost equal need for training programs in the domain of teaching skills, novice teachers had slightly higher need than experienced teachers. This finding is in line with Arslan, Mirici, \& Hüseyin (2019). They concluded that teachers with 5 years or less of teaching experience needed more training in teaching skills because of their little experience compared to those with more than five years of teaching experience.

On the other hand, the domain of Research Skills has the highest means with 4.1611 for more experienced teachers and 4.0238 for less experienced teachers, with a mean difference of 0.1373 . This finding revealed that both groups need more training sessions on the domain of research skills than other domains. Assessment Literacy also has almost the same mean difference of 0.1476 between both groups. For Educational Psychology and Material Development, the means difference of both groups is almost the same with 0.2643 and 0.2714 , respectively. Lastly, the more experienced teachers have a mean score of 3.9389 and the less experienced teachers have a mean score of 3.4762 for the Educational Technology; with a mean difference of 0.4627 which represents the highest mean difference between both groups. This means that the use of technology has the widest gap between the junior (less than 5 years) and the seniors (more than 5 years) in their need for knowledge on the use of technology in teaching. This finding indicates that the experienced teachers need more training sessions on educational technology than the novice ones which is a normal result as old teachers are familiar with traditional teaching methods. Therefore, they lack the knowledge of incorporating technology in their teaching techniques. The same result was echoed in McElearney, Murphy, \& Radcliffe (2018) where teachers with 11-20 years teaching experience faced difficulties in using technology because of their lack of technical skills.

Secondly, after tabulating the means and the standard deviation of the training needs, Independent-samples T-test was done to determine whether the mean differences between both groups are significant or not. Table 5 displays the results of Independent-samples T-test.

Table 5: Independent-samples T-test Results According to Teachers' Experience

\begin{tabular}{|c|c|c|c|c|c|c|c|c|}
\hline \multirow{3}{*}{$\begin{array}{l}\text { Training } \\
\text { Needs }\end{array}$} & \multicolumn{2}{|c|}{$\begin{array}{c}\text { Levene's Test } \\
\text { for Equality of } \\
\text { Variances }\end{array}$} & \multicolumn{6}{|c|}{ t-test for Equality of Means } \\
\hline & \multirow[t]{2}{*}{$\mathrm{F}$} & \multirow[t]{2}{*}{ Sig. } & \multirow[t]{2}{*}{$\mathrm{t}$} & \multirow[t]{2}{*}{ df } & \multirow[t]{2}{*}{$\begin{array}{l}\text { Sig. } \\
(2- \\
\text { tailed })\end{array}$} & \multirow[t]{2}{*}{$\begin{array}{c}\text { Mean } \\
\text { Differe } \\
\text { nce }\end{array}$} & \multicolumn{2}{|c|}{$\begin{array}{l}95 \% \text { Confidence } \\
\text { Interval of the } \\
\text { Difference }\end{array}$} \\
\hline & & & & & & & Lower & Upper \\
\hline $\begin{array}{c}\text { Content } \\
\text { Knowledge }\end{array}$ & 1.504 & .223 & -.154 & 85 & .878 & -.0338 & -.47035 & .40263 \\
\hline $\begin{array}{c}\text { Teaching } \\
\text { Skills }\end{array}$ & .686 & .410 & .108 & 85 & .914 & .02925 & -.50928 & .56779 \\
\hline $\begin{array}{l}\text { Management } \\
\text { Skills }\end{array}$ & 4.424 & .038 & -.788 & 78.766 & .433 & -.22672 & -.79938 & .34594 \\
\hline
\end{tabular}




\begin{tabular}{lcccccccc}
$\begin{array}{l}\text { Educational } \\
\text { Technology }\end{array}$ & 4.095 & .046 & -1.876 & 77.048 & .064 & -.46270 & -.95385 & .02845 \\
$\begin{array}{c}\text { Educational } \\
\begin{array}{l}\text { Psychology } \\
\text { Material }\end{array}\end{array}$ & 7.108 & .009 & -.997 & 72.240 & .322 & -.26429 & -.79283 & .26426 \\
$\begin{array}{c}\text { Development } \\
\text { Assessment } \\
\text { Literacy }\end{array}$ & .611 & .437 & -1.081 & 85 & .283 & -.27143 & -.77045 & .22759 \\
$\begin{array}{c}\text { Research } \\
\text { Skills }\end{array}$ & .020 & .888 & -.634 & 85 & .528 & -.13730 & -.56793 & .29333 \\
\hline
\end{tabular}

As noticed in Table 5, there is no significant difference between the more experienced teachers and the less experienced ones; $\mathrm{t}(85)=0.154, \mathrm{p}=0.878$, in terms of content knowledge. Both groups need to be trained on this topic with a difference of mean value that is negligible. There was also no significant difference between both groups; $t(85)=0.108, p=0.914$, in terms of teaching skills. The mean value of less experienced teachers is slightly higher than the more experienced teachers, but the difference is negligible. Besides that, there was also no significant difference between both groups; $t(78.766)=0.788, p=0.433$, in terms of their perceived needs to be trained with management skills. This domain was needed by the more experienced teachers more than the less experienced ones, but the difference is negligible. Furthermore, there were also no significant differences between both groups; $t(77.048)=1.876, p=0.064$, $\mathrm{t}(72.240)=0.997, \mathrm{p}=0.322$ in terms of educational technology and educational psychology, respectively. These two domains were also needed by the more experienced teachers more than the less experienced ones, but the difference is negligible. Lastly, there were also no significant differences between both groups; $\mathrm{t}(85)=1.081, \mathrm{p}=0.283, \mathrm{t}(85)=.630, \mathrm{p}=0.530$, and $\mathrm{t}(85)=0.634$, $\mathrm{p}=0.528$ in terms of material development, assessment literacy, and research skills, respectively. The mean values of more experienced teachers are higher than the less experienced ones, but the differences are also negligible.

Thus, it could be noted that both teachers experienced and novice needed training sessions in all the previous domains. This was also highlighted by the professors throughout the interviews with explicit reasons as follows.

"It's crucial for both not only important, because learning never stops for anyone, and it encourages the success of new teachers." (Training Needs $>$ Necessity of PDPs for new teachers> T4)

"... and also, for experienced teachers, they should always be up to date, and build upon their knowledge to give the best to their students." (Training Needs $>$ Necessity of PDPs for experienced teachers> T4)

"For the new ones, they will learn ABC of teaching and how to deal with the issues or the problems in your classrooms and how can you find some solutions?" (Training Needs $>$ Necessity of PDPs for new teachers $>$ T5)

"If you are experienced one, you should be updated to the newest in the field. What are the new strategies? What are the new assessment methods and tools I will use with my students, and they will be effective?" (Training Needs> Necessity of PDPs for experienced teachers> T5) 


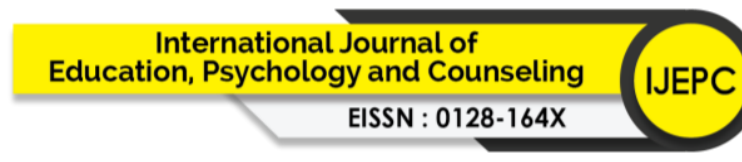

Volume 6 Issue 44 (December 2021) PP. 253-277

DOI 10.35631/IJEPC.644020

"For new teachers may be about because they need more experience how to deal with students because sometimes reading something or studying something is different when you try to implement inside the reality of the class especially that we have a huge number of students." (Training Needs $>$ Necessity of PDPs for new teachers $>$ T8)

"For experienced teacher, I think it's necessary to keep them updated and sometimes to get from their experience because they sometimes help each other even the experienced teacher. One teacher is good at for example, the content knowledge another teacher is good at technology so we can get benefit from each other." (Training Needs $>$ Necessity of PDPs for experienced teachers $>$ T8)

It could be seen from the previous excerpts that T4, T5, and T8 express how necessary are PDPs for both new and experienced teachers. They state that these programs are important for new teachers because they help them learn teaching methodology. They also mention that these training programs offer solutions of some issues that may surprise the new teachers in the classrooms without knowing how to deal with them due to their less experience. Besides that, they express that PDPs are also necessary for experienced teachers as they need to be updated to the newest trends in the field of teaching English language. Furthermore, those experienced teachers can share their knowledge and experience with the novice teachers via these training programs.

Therefore, the current study revealed that years of teaching experience is not a factor in determining EFL teachers' needs of PDPs. This scenario is also seen in the study of Hartono (2016). It was stated that both experienced and new teachers need to refresh their knowledge academically and learned new teaching visions through PDPs. Furthermore, Inamorato dos Santos, Gaušas, Mackevičiūtè, Jotautytè, \& Martinaitis (2019) mentioned that while the new academics learn new skills such as organizing courses and dealing with large numbers of students, experienced lecturers find it beneficial to improve their teaching through reflecting and rethinking after attending PDPs. In addition, Zhang, Admiraal, \& Saab (2021) suggested that PD activities should be designed to be to be more rigorous. They might concentrate on implementing novel pedagogies in the classroom as well as giving mentorship and training to new teachers.

On the other hand, the study of Qian, Hambrusch, Yadav, \& Gretter (2018) reported different findings where experienced teachers believed that they did not need PDPs as new teachers did even though they were teaching a new course. They stated that they had strong background as they expressed in the interview. These two different views can be discussed based on the adult's learning theory. One of the assumptions of this theory is that adults bring a wide range of experiences to the educational setting such as PDPs, which means that any group of adults will be diverse in terms of background, learning style, motivation, and needs (Knowles, Holton \& Swanson, 2014). Thus, PDPs planners should pay attention to the teachers' distribution to these programs according to their age or years of experience to target their needs.

\section{The Extent to which the Training Needs of EFL Teachers Met in PDPs}

Research question two aims to shed light on the training needs that have been met in the PDPs undertaken at TUELC. Since this question was based on the quantitative results of research 
Volume 6 Issue 44 (December 2021) PP. 253-277

DOI 10.35631/IJEPC.644020

question one, its answer was only obtained from the interview. A closed question in the semistructured interview was used to get the data which would illustrate the answer to this question. The closed question was "to what extent are these needs (Research Skills, Educational Psychology, Teaching Skills, Educational Technology, Management Skills, Assessment Literacy, Material Development, and Content Knowledge) met in PDPs at TUELC? The participants were asked to use these phrases: Not met, Met to a little extent, Met to a large extent, and Completely met. The participants' responses were demonstrated in Table 6.

Table 6: The Extent to which Training Needs were Met in PDPs Based on the Participants' Responses in the Interview

\begin{tabular}{|c|c|c|}
\hline Training Needs & Degree of Meeting & Number of Teachers \\
\hline \multirow{4}{*}{ Teaching Skills } & Not met & ---- \\
\hline & Met to a little extent & ---- \\
\hline & Met to a large extent & 2 \\
\hline & Completely met & 6 \\
\hline \multirow{4}{*}{ Educational Technology } & Not met & ---- \\
\hline & Met to a little extent & $\begin{array}{ll}--- \\
\end{array}$ \\
\hline & Met to a large extent & 2 \\
\hline & Completely met & 6 \\
\hline \multirow{4}{*}{ Management Skills } & Not met & $\begin{array}{ll}--- \\
--1\end{array}$ \\
\hline & Met to a little extent & 3 \\
\hline & Met to a large extent & 5 \\
\hline & Completely met & ---- \\
\hline \multirow{4}{*}{ Educational Psychology } & Not met & $\begin{array}{ll}--- \\
\end{array}$ \\
\hline & Met to a little extent & 3 \\
\hline & Met to a large extent & 5 \\
\hline & Completely met & ---- \\
\hline \multirow{4}{*}{ Research Skills } & Not met & ---- \\
\hline & Met to a little extent & 5 \\
\hline & Met to a large extent & 3 \\
\hline & Completely met & $\begin{array}{ll}--- \\
\end{array}$ \\
\hline \multirow{4}{*}{ Assessment Literacy } & Not met & $\begin{array}{ll}--- \\
\end{array}$ \\
\hline & Met to a little extent & 4 \\
\hline & Met to a large extent & 4 \\
\hline & Completely met & ---- \\
\hline \multirow{4}{*}{ Content Knowledge } & Not met & 3 \\
\hline & Met to a little extent & 5 \\
\hline & Met to a large extent & ---- \\
\hline & Completely met & ---- \\
\hline \multirow{4}{*}{ Material Development } & Not met & 3 \\
\hline & Met to a little extent & 5 \\
\hline & Met to a large extent & $\begin{array}{ll}--- \\
\end{array}$ \\
\hline & Completely met & $\begin{array}{ll}--- \\
\end{array}$ \\
\hline
\end{tabular}

It could be seen from the table above that Teaching Skills and Educational Technology have been met to a large extent or completely met. This means that PDPs at TUELC discussed these 


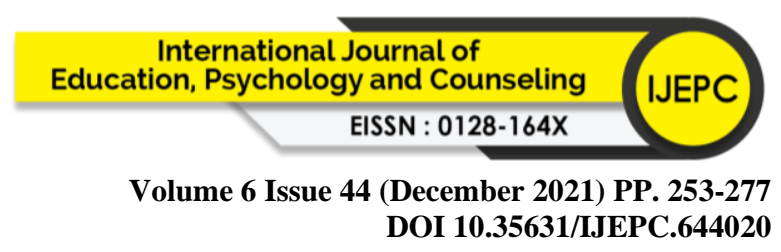

two domains more in the workshops and in the symposiums organized for their teachers. This finding is stated by teachers' responses in the interview as follows.

"For teaching skills, I learned a lot of techniques, approaches during the workshops of PDPs. So, it is completely met." (The Extent to which the Training Needs are Met> Teaching Skills>T3).

"For teaching skills, the PDPs do talk about teaching skills a lot. They have focused on different teaching skills. Such as teaching grammar and writing and many different aspects. So, I think it is completely met." (The Extent to which the Training Needs are Met> Teaching Skills>T7).

"The domain of teaching skills is met to a large extent. There were many training sessions discussed this topic." (The Extent to which the Training Needs are Met> Teaching Skills>T8).

Based on the above excerpts, it could be seen that T1, T7, and T8 mentioned that the field of teaching skills was discussed more than other topics in the PDPs at TUELC. This means that their training needs for teaching skills were completely met or met to a large extent during these programs.

Regarding the educational technology, T1 stated that:

"I have attended many training sessions on educational technology and how to use apps and different sites to teach English. So, I think it is completely met." (The Extent to which the Training Needs are Met> Educational Technology>T1).

Additionally, T3 mentioned that:

"For educational technology, it is met to a large extent. I learned a lot of websites, and I used these websites during my teaching classes." (The Extent to which the Training Needs are Met> Educational Technology>T3).

Besides, T6 said that:

"For educational technology, it is completely met. They do a lot of training sessions to talk about applications and new technologies, new forms of, you know, online stuff. So, they do focus on this more." (The Extent to which the Training Needs are Met> Educational Technology>T3).

The excerpts above show that the teachers are pleased with the training sessions that discussed the topic of educational technology. They stated that their training needs for educational technology were completely met or met to a large extent during PDPs at TUELC. 


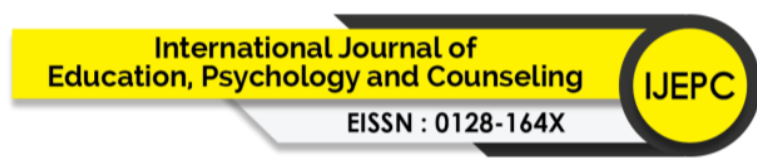

Volume 6 Issue 44 (December 2021) PP. 253-277

DOI 10.35631/IJEPC.644020

Thus, it is a good point to focus on these two dimensions as EFL teachers need more trainings in teaching skills such as teaching productive and receptive skills, teaching vocabulary and language function, and teaching methodology, and in educational technology as mentioned by Raud \& Orehhova (2017); Spencer, Harrop, Thomas \& Cain (2018); Hazaea (2019); and Shabani, Alibakhshi, Bahremand, \& Karimi (2019). The responses received from teachers during the interview explained why teachers need to attend more training sessions in these two domains. For teaching skills, they said:

"Some teachers have the language skills, they got eight in IELTS, but their teaching wasn't that good. So they have you know only the linguistic or the content knowledge, but they don't know how to deliver it to their students." (Most important training needs $>$ Teaching Skills $>$ T1).

"Each teacher needs to know how to teach well, and she or he cannot do this without you know, knowing the best skills to teach." (Most important training needs > Teaching Skills >T3).

"Teaching skills are important because I believe sometimes the teacher has the knowledge, but she cannot move it or express it to her students. And this is a big problem because sometimes you are good in information, but you can't teach students, so I like to keep improving myself in teaching skills. " (Most important training needs > Teaching Skills > T8).

From the excerpts above, T1, T3, and T8 expressed how EFL teachers need to improve themselves in teaching skills. They said although some teachers have the content knowledge of English language, they still lack the skills of delivering it to their students. They need to learn the pedagogy and methodology which means the practical side besides the theoretical one. Lacking teaching methodology will affect the students' outcomes. This means that if the teachers do not know how to teach and their practices inside the classrooms are not improved, the results on students' achievement will be affected as the students' learning is the final result that occurred after the teachers attended PDPs. This what is stated in Kirkpatrick's evaluation model. It is mentioned that the results, which is the last level of evaluating training program, depend on the previous level which is behaviour. This behaviour is embodied in teachers' teaching practices inside their classrooms (Kirkpatrick \& Kirkpatrick, 2006).

Similarly, the participants' responses in the interview also showed why teachers need to be trained on educational technology.

"In our situation, you know, we have been teaching online for a year now, almost a year. So I think educational technology is also important." (Most important training needs $>$ Educational Technology $>$ T1).

"It is important as we are living now of COVID-19 you know, everything is changed and transferred from face to face environment to online environment or remote environment. So, the educational technology is very very important to deal with." (Most important training needs $>$ Educational Technology $>$ T5). 


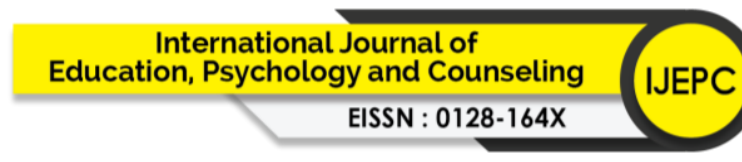

Volume 6 Issue 44 (December 2021) PP. 253-277

DOI 10.35631/IJEPC.644020

"Educational technology is important especially during the pandemic and after the pandemic this has become a very very integral part of how we go about as a teacher so that is very, very important." (Most important training needs > Educational Technology > T7).

It could be seen from the excerpts above the reasons why teachers need to learn more about technology. They stated that due to the pandemic of COVID-19, all teaching and learning activities have been transferred online. It means that all teachers should have the technological skills that allow them to deal with technology and websites as they are the connection point between them and their students. According to the study of Arslan, Mirici, \& Hüseyin (2019), they stated that the course content of any training programs should include using instructional technology in teaching. Also, Shabani, Alibakhshi, Bahremand, \& Karimi (2019) have investigated the professional needs of EFL teachers in training programs and found that the second important component of PDPs was educational technology that included electronic learning, social networks/multimedia, and educational devices.

Furthermore, Table 6 illustrated that Management Skills, Educational Psychology, Research Skills, and Assessment Literacy, according to the teachers' responses in the interview, were in the average level of being met in PDPs. It means that 3 teachers said that Management Skills and Educational Psychology were met to a little extent, and 5 teachers stated that they were met to a large extent. For Research Skills, 5 teachers said that it was met to a little extent, and 3 teachers stated that it was met to a large extent. Finally, half of the teachers (4) stated that Assessment Literacy was met to a little extent, and the other half stated that it was met to a large extent. This finding is expressed in teachers' responses as follows.

"For educational psychology, it is met to a little extent, because I've attended only two sessions about psychology and it's not completely about psychology, but it's about learning through laughing and these things." (The Extent to which the Training Needs are Met> Educational Psychology>T2).

"For management skills, for me, it is met to a large extent. I learned a lot during the Cambridge press workshops. They really taught us how to deal with large number of students, how to manage the time with this large number of students, and how to deal with the different abilities among students and so on." (The Extent to which the Training Needs are Met> Management Skills>T3).

"Assessment literacy is met to a little extent, because I do lead the Special Interest Group (one of the PDPs) which assigned for assessment topics. I do see very few numbers of teachers who would like to talk about assessment in the training sessions. So, there were few sessions discussed this topic." (The Extent to which the Training Needs are Met> Assessment Literacy>T6).

"I think for research skills, we did some professional development programs, but I don't think it is met cmpletely. I think it is met to a little extent." (The Extent to which the Training Needs are Met> Research Skills>T7).

This result shows that these four topics were presented in PDPs with different proportion based on teachers' points of view. Therefore, PDPs' planners should give these topics the same 


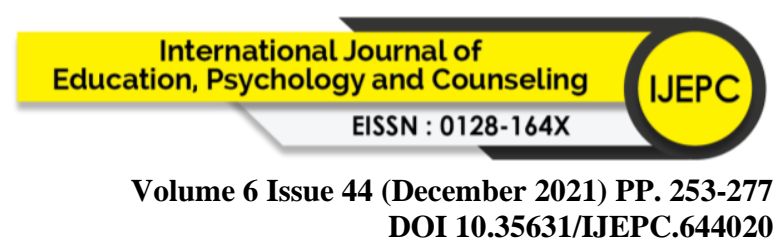

amount of training sessions as most of the teachers during the interview mentioned that they still need training sessions on these topics. Following are some of their responses.

"The second most important training topic is management skills. We teach large classes, more than 50 students in a class, and some teachers lose control over their classes. Therefore, we need to learn more about how to manage large classes." (Topics Need More Training> Management skills> T1).

"For the management skills, we are dealing with a very large number of students. So, I think we need more training sessions in management skills. We need to know how to manage those students." (Topics Need More Training > Management skills> T3).

Based on the excerpts above, it could be noticed that due to the large number of students in one class, teachers need to learn about management strategies and how to control these large classes. This finding was echoed in Arslan, Mirici, \& Hüseyin's study (2019) in which classroom management skills was to be found among the core needs that EFL teachers needed to improve. Furthermore, Gakwerere, Harerimana, \& Mukamazimpaka (2020) mentioned that frequent training sessions should be held for all teachers to foster efficient classroom management practices.

"As for educational psychology, I think we face a problem that most of the students are not willing to learn English. So, we need to know something about the psychology of the learner to know what kind of motivation they need, and what's the correct motivation? how to create it? Yeah, I think it is very important to understand the psychology of the learner." (Topics Need More Training > Educational Psychology> T2).

"I think in my opinion that educational psychology is very important. Because Ineed to learn more about my students, their needs, their abilities to know what they need, and how to teach them and to get the best of the learning outcomes." (Topics Need More Training > Educational Psychology> T4).

"For the educational psychology, teacher should be aware of some theory that describe the nature of learner's psychology and how they are different. How the learners or students have individual differences. And how can teachers deal with these differences in a good way. Also, teachers should know through educational psychology that there are different styles of learners, some learners are visual, others are auditory, ... etc." (Topics Need More Training> Educational Psychology> T5).

Additionally, it could be also noticed from the excerpts above that T2, T4, and T5 stated that learning about students' psychology would help them to know their abilities and their learning styles which, as a result, would influence their academic achievement. They also mentioned that if they were offered training sessions on this topic, they would know how to motivate their 


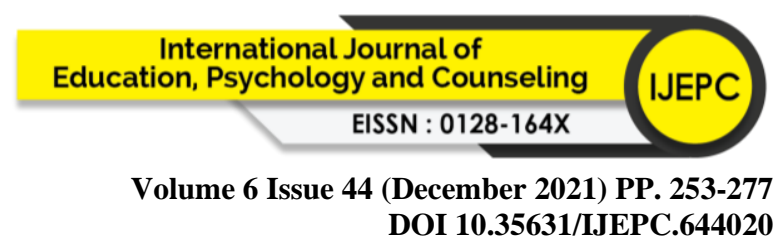

students to learn, and how to deal with individual differences properly. Shabani, Alibakhshi, Bahremand, \& Karimi (2019) stated that EFL teachers need to take courses on four main areas, one of them is educational psychology.

"We still need training sessions on assessment literacy, because we write a lot of quizzes, and if a teacher knows how to construct a very good quiz, this will make it easier for the coordinator and the testing unit to proofread teachers' quizzes." (Topics Need More Training> Assessment literacy> T1).

"I think I would go with the assessment literacy, because this is also very important skill for the teacher to acquire because without this skill, she cannot assess her students. Assessment is a crucial thing to do during teaching." (Topics Need More Training > Assessment literacy> T3).

Finally, these excerpts show that teachers need also to have training courses in assessment literacy. T3 mentioned that learners' assessment is a vital part in teaching context and every teacher should have this skill. On the same path, T1 stated that EFL teachers write a lot of tests and quizzes and if they know how to prepare them well, it will be easy for the testing unit to proof their exams. The study of Zulaiha \& Mulyono (2020) indicated that the three essential items that reflected teachers' assessment literacy training needs included "selecting tests for use", "writing test specifications", and "writing tasks and items". These three areas were considered the primary needs of teachers in improving their assessment literacy abilities.

On the other hand, although Content Knowledge and Material Development were considered important needs to be trained on based on their mean scores in the results of research question one, all teachers' responses in the interview stated that these two domains were not met or met to a little extent in the undertaken PDPs at TUELC as shown in Table 6. This could be seen clearly in the following excerpts from teachers' interview.

"Regarding content knowledge, I don't think that we have addressed it in our PDPs or at least as far as I know. So, content knowledge is not met." (The Extent to which the Training Needs are Met> Content Knowledge >T1).

"For the content knowledge topic, I would that it is met to a little extent. I couldn't recall many workshops about this content." (The Extent to which the Training Needs are Met> Content Knowledge > T3).

"For material development, we had few workshops about it, very few. Thus, it is met to a little extent." (The Extent to which the Training Needs are Met> Material Development >T5).

"In terms of For material development, although we have been facing problems, especially with some new courses, this topic was not discuused in PDPs. So, it is not met for me." (The Extent to which the Training Needs are Met> Material Development $>$ T7). 


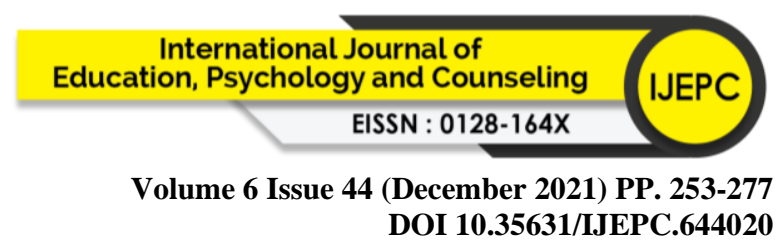

These excerpts clarify that there were only few training sessions which discussed these two topics, and this is a crucial issue for the PDPs designers. Not covering these topics in PDPs does not mean that they are not important. Thus, the planners of PDPs need to pay more attention to these two domains because EFL teachers still need training sessions in content knowledge and material development as mentioned by some teachers in the interview.

"Content Knowledge, I think it's also important for the teacher to improve her knowledge about the language itself. Especially that sometimes we have different studies and new studies. We need to be updated." (Content Knowledge > Improvement Training Topic> T8).

"It's very important because content knowledge is a crucial part of the teacher training, because improving as I said, improving your content knowledge positively affect the quality of instruction." (Content knowledge > Crucial Part in Teaching > T4).

"As for material development, it's important experience for English language teachers. I need to have my own materials inside the class, because sometimes it's a waste of time. There are millions of materials available online, but it's good to participate in this field to have this experience on how to create materials." (Material development $>$ Save Time $>$ T2).

"And also material development, I think it is very crucial because preparation of good and ideal teaching materials will optimize the learning in learner engagement and the transfer of knowledge between me and the learner." (Material development> Optimizing learning > T4).

Based on the excerpts above, T8 mentioned that EFL teachers need to improve their content knowledge regarding English Language such as grammar, pronunciation, language acquisition, and so on in order to be updated with the newest information in this field. Teachers need to build on their prior knowledge and develop it because there are many new studies that are conducted in the field of English Language. Also, T4 stated that content knowledge is a crucial part in teaching English language. If an EFL teacher lacks the basic knowledge of the language, the quality of instruction will be affected negatively. This finding is consistent with the study of Önalan \& Gürsoy (2020) in which most of the participants $(86,7 \%)$ did not think that the in-service trainings add to their theoretical knowledge which they learned at the faculty. This means that the theoretical knowledge required significant attention in the training sessions. Therefore, in line with some researchers interested in the field, it can be argued that content knowledge needs to be learned continuously (Czerniawski, et al., 2018; Lich 2015; NaliakaMukhale \& Hong, 2017).

Besides, it could be seen from the responses of T2 and T4 that teachers need to have their own materials in order to save time and to optimize the learning process as these materials will contribute in transferring the knowledge in a better way. That is why they need to attend training sessions which focus in material development. This is also supported by Arslan, Mirici, \& Hüseyin (2019), whose findings revealed that material development domain was one of the central professional training needs of EFL teachers. Also, the suggested scale by Shabani, 


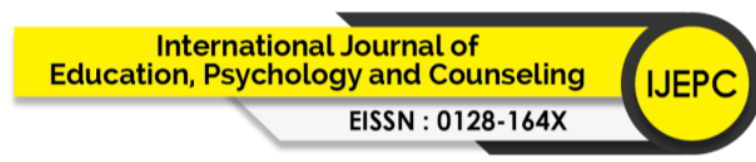

Volume 6 Issue 44 (December 2021) PP. 253-277

DOI 10.35631/IJEPC.644020

Alibakhshi, Bahremand, \& Karimi (2019) for assessing the EFL teachers' professional development needs in language institutes and teacher development centers included material development as a main area.

\section{Conclusion}

The findings from this study attempt to fill in a gap in knowledge that is associated to professional development area. It is hoped that this study will have significant contributions through the valuable feedback given by teachers and needed by makers of teachers education programs. Their feedback illustrated that the most three domains to be trained on which were research skills, educational psychology, and teaching skills. It is also confirmed that meeting teachers' needs in PDPs is a crucial part in motivating teachers' participation in these programs.

It was found that the success of PDPs depends on identification and understanding teacher's perceptions and needs before the creation of the programs. Therefore, universities and PDPs providers need to focus on their teachers' needs and take them into consideration in designing and implementing these programs. The instructors of this study placed a high need to the domains of research skills, educational psychology, and teaching skills which are relevant to the EFL teachers' needs. Thus, teachers at universities should be provided with enough training sessions in these areas to enhance their teaching practices and their students' outcomes. Besides that, other domains like educational technology, assessment literacy, and management skills should also be included in PDPs as participants of this study rated them as important needs to be trained on.

This study has focused only on one PDP at one university in Saudi Arabia. Further research can address this issue from different perspectives looking at different professional development programs at different institutions in Saudi Arabia and make a comparison between them. This will make the findings more generalisable to the whole Kingdom of Saudi Arabia. In addition, since this study examined EFL teachers' needs at universities, it is a good idea to conduct future studies on EFL teachers at schools. Such research may produce different data sets that would better be compared with the current study findings.

Finally, the researcher is hopeful that this study has done its part in contributing to the knowledge of teacher education and professional development in particular. By taking the right steps, the PDPs can promote positive and continuous change in the education system on which the society depends to produce graduates who are able to cope confidently with the global development.

\section{References}

Alhojailan, M. I. (2012). Thematic analysis: A critical review of its process and evaluation. West East Journal of Social Sciences, 1(1), 39-47.

Arslan, S., Mirici, İ. H., \& Hüseyin, Ö. Z. (2019). In-service training needs of EFL teachers in non-formal education settings. Selçuk Üniversitesi Edebiyat Fakültesi Dergisi, (42), 223-244.

Asmari, A. Al. (2016). Continuous Professional Development of English Language Teachers: Perception and Practices. Advances in Language and Literary Studies, 7(3).

Boudersa, N. (2016). The importance of teachers' training programs and professional development in the Algerian educational context: Toward informed and effective teaching practices. Expériences Pédagogiques, 1. 


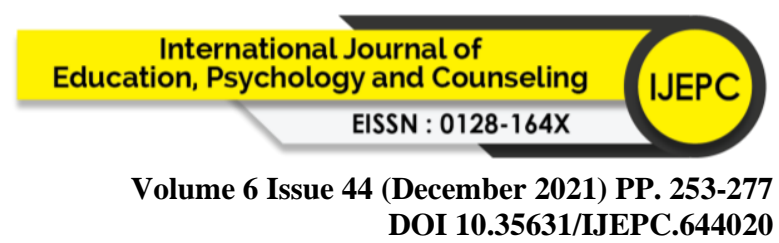

Brown, A., \& Danaher, P. A. (2019). CHE principles: Facilitating authentic and dialogical semi-structured interviews in educational research. International Journal of Research \& Method in Education, 42(1), 76-90.

Castleberry, A., \& Nolen, A. (2018). Thematic analysis of qualitative research data: Is it as easy as it sounds? Currents in Pharmacy Teaching and Learning, 10(6), 807-815.

Creswell, J. W., \& Clark, V. L. P. (2018). Designing and conducting mixed methods research. Sage publications.

Czerniawski, G., Gray, D., MacPhail, A., Bain, Y., Conway, P., \& Guberman, A. (2018). The professional learning needs and priorities of higher-education-based teacher educators in England, Ireland and Scotland. Journal of Education for Teaching, 44(2), 133-148.

Darling-Hammond, L., Hyler, M. E., Gardner, M. (2017). Effective Teacher Professional Development. Palo Alto, CA: Learning Policy Institute.

Fang, G., Chan, P. W. K., \& Kalogeropoulos, P. (2021). Secondary School Teachers' Professional Development in Australia and Shanghai: Needs, Support, and Barriers. SAGE Open, 11(3), 1-11.

Gakwerere, M., C., Harerimana, J., P. \& Mukamazimpaka, M., C. (2020). Classroom Management Strategies and Students' Drop out in Public Secondary Schools in Rwanda, a Case of Musanze District. Journal of Education, 3(6), 53-75.

Hartono, R. (2016). Indonesian EFL teachers' perceptions and experiences of professional development. Indiana University of Pennsylvania.

Hazaea, A. (2019). The Needs on Professional Development of English Language Faculty Members at Saudi University. International Journal of Educational Researchers, 10(1), $1-14$.

Inamorato dos Santos, A., Gaušas, S., Mackevičiūte, R., Jotautyte, A., Martinaitis, Ž. (2019). Innovating Professional Development in Higher Education: Case Studies. Publications Office of the European Union.

Kirkpatrick, D., \& Kirkpatrick, J. (2006). Evaluating training programs: The four levels. Berrett-Koehler Publishers.

Knowles, M. S., Holton III, E. F., \& Swanson, R. A. (2014). The adult learner: The definitive classic in adult education and human resource development. New York, NY: Routledge.

Laerd.com. (2020). Purposive sampling/Laerd dissertation. Retrieved June 10, from https://dissertation.laerd.com/purposive-sampling.php\#total

Lee, S. M. (2016). EFL Teachers' Perceptions of the Needs and Effectiveness of Professional Development in Korean Christian Higher Education. Unpublished dissertation.

Lich, D. D. (2015). An Investigation into Tertiary EFL Teachers' Needs for Professional Development. In Conference paper on the 6th International Conference on" Responding to Challenges of Teaching English for Communication", At SEAMEO Regional Training Center.

Liem, A. (2018). Interview schedule development for a sequential explanatory mixed method design: Complementary-alternative medicine (CAM) study among Indonesian psychologists. International Journal of Social Research Methodology, 21(4), 513-525.

Macias, A. (2017). Teacher-Led Professional Development: A Proposal for a Bottom-Up Structure Approach. International Journal of Teacher Leadership, 8(1), 76-91.

McElearney, A., Murphy, C., \& Radcliffe, D. (2018). Identifying teacher needs and preferences in accessing professional learning and support. Professional Development in Education, 45(3), 433-455. 


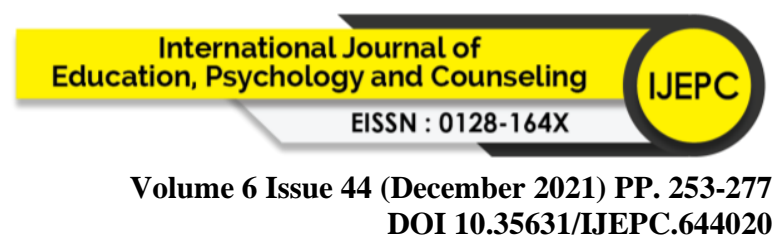

Moeini, H. (2008, December). Identifying needs: A missing part in teacher training programs. In Seminar. net, 4 (1).

NaliakaMukhale, P., \& Hong, Z. (2017). Towards Improvement of Student Learning Outcomes: An Assessment of the Professional Development Needs of Lecturers at Kenyan Universities. Journal of Education and Practice, 8(12), 151-158.

Nijakowska, J., Tsagari, D., \& Spanoudis, G. (2018). English as a foreign language teacher training needs and perceived preparedness to include dyslexic learners: The case of Greece, Cyprus, and Poland. Dyslexia, 24(4), 357-379.

Önalan, O., \& Gürsoy, E. (2020). EFL teachers' views and needs on in-service training as a part of professional development: A case study in Turkish context. Bartın University Journal of Faculty of Education, 9(2), 373-387.

Oudah, F., \& Altalhab, S. (2018). Saudi EFL Teaching Training Programmes: Teachers' Perceptions and Needs. Theory and Practice in Language Studies, 8(11), 1407.

Palinkas, L. A., Horwitz, S. M., Green, C. A., Wisdom, J. P., Duan, N., \& Hoagwood, K. (2015). Purposeful sampling for qualitative data collection and analysis in mixed method implementation research. Administration and policy in mental health and mental health services research, 42(5), 533-544.

Powell, C. G., \& Bodur, Y. (2019). Teachers' perceptions of an online professional development experience: Implications for a design and implementation framework. Teaching and Teacher Education, 77, 19-30.

Qian, Y., Hambrusch, S., Yadav, A., \& Gretter, S. (2018). Who needs what: Recommendations for designing effective online professional development for computer science teachers. Journal of Research on Technology in Education. 50(2), 164-181.

Raud, N., \& Orehhova, O. (2017). In-service training of teachers of English as a foreign language in estonia: mapping of trends and opportunities. Problems of Education in the 21st Century, 75(2), 194-203.

Roy, C. K., Rahim, S., \& Khojah, A. Y. (2018). Perceptions of EFL Teachers at King Abdulaziz University Regarding the Effectiveness of Cambridge University Press's Train the Trainer Course. Arab World English Journal, 9(2), 92-107.

Shabani, M. B., Alibakhshi, G., Bahremand, A., \& Karimi, A. R. (2019). In-service Professional Development Scale for EFL Teachers: A Validation Study. International Journal of Humanitites, 25(3), 63-78.

Spencer, P., Harrop, S., Thomas, J., \& Cain, T. (2018). The professional development needs of early career teachers, and the extent to which they are met: a survey of teachers in England. Professional development in education, 44(1), 33-46.

Subekti, A. S. (2020). Training of Academic Writing for Senior High School English Teachers: Formulating Research Questions. E-Dimas: Jurnal Pengabdian kepada Masyarakat, 11(4), 432-439.

Tawalbeh, T. I. (2015). Instructors' Perceived Effectiveness of Current Professional Development Programs at Taif University English Language Center. English Language Teaching, 8(11), 117-130.

Topkaya, E., \& Çelik, H. (2016). Non-native English language teachers' perceptions of professional development: Implications for career Stages. Procedia-Social and Behavioral Sciences, 232, 5-11.

Wichadee, S. (2011). Professional Development: A Path to Success For EFL Teachers. Contemporary Issues in Education Research (CIER), 4(5), 13-22. 


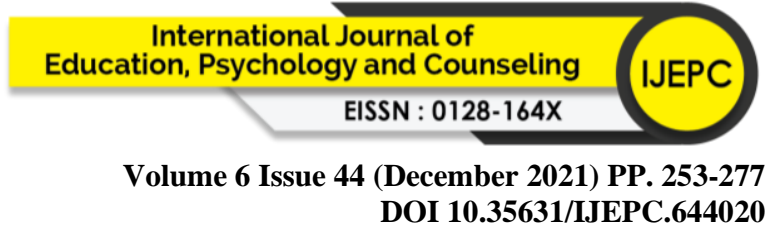

Zein, M. S. (2016). Professional development needs of primary EFL teachers: perspectives of teachers and teacher educators. Professional Development in Education, 43(2), 293313.

Zhang, M., Parker, J., Koehler, M. J., \& Eberhardt, J. (2015). Understanding Inservice Science Teachers' Needs for Professional Development. Journal of Science Teacher Education, 26(5), 471-496.

Zhang, X., Admiraal, W., \& Saab, N. (2021). Teachers' motivation to participate in continuous professional development: relationship with factors at the personal and school level. Journal of Education for Teaching, 1-18.

Zulaiha, S., \& Mulyono, H. (2020). Exploring junior high school EFL teachers' training needs of assessment literacy. Cogent Education, 7(1), 1-13. 